\title{
Comparison of mRNA contents of interleukin-1 $\beta$ and nitric oxide synthase in pancreatic islets isolated from female and male nonobese diabetic mice
}

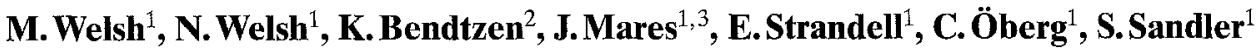 \\ ${ }^{1}$ Department of Medical Cell Biology, Uppsala University, Uppsala, Sweden \\ ${ }^{2}$ Laboratory of Medical Immunology, University Hospital, Copenhagen, Denmark \\ ${ }^{3}$ Institute of Biology and Medical Genetics, Second Faculty of Medicine, Prague, Czech Republic
}

\begin{abstract}
Summary Interleukin-1 $\beta$ (IL-1 $\beta$ ) has been suggested to mediate beta-cell destruction in insulin-dependent diabetes mellitus (IDDM) by inducing nitric oxide production. In this study, we assessed the levels of IL- $1 \beta$ and the inducible form of nitric oxide synthase (iNOS), using a semi-quantitative polymerase chain reaction assay, and performed determinations of nitrite accumulation and IL- $1 \beta$ bioactivity, on pancreatic islets isolated from 5- and 16-week-old female and male nonobese diabetic (NOD) mice and from nondiabetes prone NMRI mice. NOD mouse islets contained notable amounts of IL- $1 \beta$ mRNA. At 5 weeks of age, but not at 16 weeks, the values were higher in islets isolated from NOD females compared to males. The IL-1 $\beta$ bioactivity showed differences roughly reflecting the mRNA levels in the NOD mouse islets. In the NMRI mouse islets the IL- $1 \beta$ bioactivity was very low. The expression of iNOS mRNA increased in both male and female islets be-
\end{abstract}

tween 5 and 16 weeks of age. Immunocytochemistry of pancreatic sections indicated the presence of macrophages especially in the peri-insular area of the NOD mice which suggests that IL- $1 \beta$ was produced by macrophages. The levels of IL- $\beta$ activity and mRNA in freshly isolated islets from NOD 5-weekold females did not correlate to the iNOS mRNA content or to the nitrite production. However, after incubation with IL-1 $\beta$ in vitro, both NOD and NMRI islets responded with a marked increase in nitric oxide production. It is concluded that the presence of IL$1 \beta$ in isolated NOD mouse islets, via an induction of iNOS expression and nitric oxide production, cannot explain the gender difference in diabetes incidence in NOD mice. [Diabetologia (1995) 38: 153-160]

Key words Autoimmunity, diabetes mellitus, interleukin-1, nitric oxide, nitric oxide synthase, NOD mice, pancreatic islets, polymerase chain reaction.
Received: 8 April 1994 and in revised form: 29 August 1994

Corresponding author: Dr. S.Sandler, Department of Medical Cell Biology, Uppsala University, P. O.Box 571, S-751 23 Uppsala, Sweden

Abbreviations: BB, BioBreeding; GAPDH, glyceraldehyde-3phosphate dehydrogenase; IDDM, insulin-dependent diabetes mellitus; iNOS, inducible form of nitric oxide synthase; IL- $1 \beta$, interleukin- $1 \beta$; IL- 1 ra, interleukin- 1 receptor antagonist protein; IL-6, interleukin-6; NMRI, Naval Marine Research Institute; NO, nitric oxide; NOD, nonobese diabetic; PAP, peroxidase-antiperoxidase; PCR, polymerase chain reaction; SDS, sodium dodecyl sulphate; TNF, tumour necrosis factor; OD, optical density.
Cytokines, in particular interleukin-1 $\beta$ (IL-1 $\beta$ ), have been postulated to be important mediators of pancreatic beta-cell destruction during the process of insulitis preceding the onset of insulin-dependent diabetes mellitus (IDDM) [1,2]. A large body of experimental data has shown an inhibitory and even a toxic action of IL-1 $\beta$ on rodent beta-cells [3-6]. A major component of the IL- $1 \beta$-induced beta-cell inhibition has been attributed to nitric oxide (NO) formation catalysed by iNOS [7-9]. However, evidence demonstrating the actual presence or production of IL- $1 \beta$ and NO in the close vicinity of the pancreatic betacells in conjunction with development of IDDM is scarce. In this context it has been reported, using in situ hybridization, that in pancreatic sections of diabetes-prone BB rats IL-1-, tumour necrosis factor 
(TNF) - and IL-6-positive cells were seen in the periinsular area in $8-26 \%$ of the islets [10]. In addition, it has been shown by in situ hybridization techniques that normal mouse islet cells, most likely beta-cells, possess type 1 receptors for IL-1 [11]. Moreover, the presence of iNOS has been demonstrated by immunocytochemistry in the islets of Biobreeding (BB) rats [12].

Currently we have studied pancreatic islets from IDDM-prone NOD mice, which exhibit a marked pancreatic insulitis prior to onset of hyperglycaemia [13-15]. In most NOD mouse colonies there is a sex difference, with the females showing a much higher incidence of diabetes than the males, despite a similar degree of insulitis. We have previously found that it is feasible to isolate inflamed pancreatic islets with the infiltrating immune cells present together with the islet cells [16]. In such islets, obtained from female and male mice, we have aimed to assess the expression of the IL- $1 \beta$ gene as well as the gene for IL1 ra [17] and iNOS, by a semi-quantitative polymerase chain reaction (PCR) assay, in order to elucidate if gender differences exist in the expression of these genes.

\section{Materials and methods}

Animals and islet isolation. NOD mice were obtained from a locally inbred colony, which was originally derived from three breeding pairs received from the Clea Company, Aobadi, Japan in 1988. The colony was re-derived in 1991-1992 by Caesarean delivery, due to a decreasing diabetes incidence and mouse hepatitis virus infection. The colony has subsequently been maintained under specific pathogen-free conditions. The spontaneous diabetes incidence is now approximately $62 \%$ in the females and $10 \%$ in the males at 30 weeks of age. Female and male mice, aged 5, 12 or 16 weeks were used in the present study. All animals had free access to autoclaved water and pelleted food (Type R3; Ewos, Södertälje, Sweden). The majority of animals in the colony are becoming diabetic (blood glucose $>12 \mathrm{mmol} / 1$ plus glucosuria) after 16 weeks of age. However, since the yield of islets per pancreas upon collagenase isolation declines considerably with age, islets were not isolated from animals older than 16 weeks.

Pancreatic islets were isolated and hand-picked following collagenase digestion as described in detail elsewhere [18]. Islets from the NOD mice were immediately used, except in one set of experiments where they were cultured free-floating at $37^{\circ} \mathrm{C}$ (humidified air $+5 \% \mathrm{CO}_{2}$ ) for 1 week in medium RPMI $1640+10 \%$ fetal calf serum (Northumbria Biologicals, Cramlington, UK). The culture medium was changed every other day. In some experiments islets were also isolated from 12-14 week-old non-diabetes prone-male NMRI mice (ALAB, Sollentuna, Sweden). Experiments were also performed on a rat insulinoma cell line (RINm5F) [19]. These cells were grown in flasks allowing cell attachment, but otherwise under the same conditions as those described above for the mouse islets. The cells were grown until they reached 50 $70 \%$ confluency, incubated with or without $25 \mathrm{U} / \mathrm{ml}$ of IL- $1 \beta$ for $24 \mathrm{~h}$ and then harvested. Approximately $5 \times 10^{6}$ cells were used for each experiment. IL-1 $\beta$ was kindly provided by Dr. K. Hejnæs (Novo-Nordisk, Bagsværd, Denmark).
Isolation of $m R N A$, synthesis of $c D N A$, and PCR. Groups of $1000-2000$ islets were used for $\mathrm{mRNA}$ isolation. For this purpose a commercially available kit was used in accord with the manufacturers' instruction manual (Micro-Fast Track; Invitrogen, San Diego, Calif., USA).

First strand cDNA was synthesized with the aid of Riboclone cDNA synthesis system (Promega Biotech, Madison, Wis., USA) using $1 \mu \mathrm{g}$ mRNA. RNA was then hydrolysed in $0.5 \mathrm{~mol} / 1 \mathrm{NaOH}$ at $55^{\circ} \mathrm{C}$ for $15 \mathrm{~min}$ after which DNA was ethanol precipitated and subsequently dissolved in $100 \mu \mathrm{H}_{2} \mathrm{O}$. cDNA samples $(0.5-5 \mu l)$ were used for the amplification reactions with $0.2 \mu \mathrm{mol} / \mathrm{l}$ of the primers and the components of the $\mathrm{PCR}$ reactions provided by the GeneAmp kit (Perkin Elmer Cetus, Norwalk, Conn., USA). Two cycles of $94^{\circ} \mathrm{C}(1 \mathrm{~min})$, $37^{\circ} \mathrm{C}(3 \mathrm{~min})$, and $72^{\circ} \mathrm{C}(1 \mathrm{~min})$ were run before 25 cycles of $94^{\circ} \mathrm{C}(1 \mathrm{~min}), 55^{\circ} \mathrm{C}(2 \mathrm{~min})$ and $72^{\circ} \mathrm{C}(1 \mathrm{~min})$.

A pair of specific oligonucleotide primers (sense primer $5^{\prime}$ TTC CAG GAT GAG GAC ATG-3'; position 327-344 and antisense primer $5^{\prime}-$ CTT TTC CAT CTT CTT CTT-3'; position 719-702) were used, based on the nucleotide sequence of the murine IL- $1 \beta$ cDNA [20].

The presence of mRNA for IL-1 ra was also analysed by PCR in the samples. Two specific oligonucleotide primers were used (sense primer 5'-TGG GAT GTT AAC CAG AAG-3'; position 144-162 and antisense primer 5'-CTC CTG GAA GTA GAA TTT-3'; position 548-531) according to the sequence of the human IL-1 ra cDNA [21]. Finally, two specific oligonucleotide primers (sense primer $5^{\prime}-\mathrm{ATG}$ GCT TGC CCC TGG AA-3'; position 185-201 and antisense primer 5'-GGG TCC TCT GGT CAA ACT-3'; position 553-536) were used to demonstrate the murine macrophage form of nitric oxide synthase [22-24]. PCR amplification of the enzyme GAPDH, using oligonucleotides corresponding to positions 104-122 and 323-305 of the human cDNA [25], were run on all samples in parallel [26] to compensate for differences in cell number, RNA isolation and cDNA synthesis [27]. The samples were electrophoresed on $1.2 \%$ agarose gels for Southern blot analysis [28] hybridizing the blot with the ${ }^{32} \mathrm{P}$-labelled DNA probes, at $42^{\circ} \mathrm{C}$ in $50 \%$ formamide. The blots were washed $3 \times 5 \mathrm{~min}$ each at $20^{\circ} \mathrm{C}$ in $150 \mathrm{mmol} / 1 \mathrm{NaCl}+$ $15 \mathrm{mmol} / \mathrm{l} \mathrm{NaCitrate}+0.1 \%$ SDS and further washed $3 \times$ $30 \mathrm{~min}$ at $50^{\circ} \mathrm{C}$ in $15 \mathrm{mmol} / 1 \mathrm{NaCl}+1.5 \mathrm{mmol} / \mathrm{l} \mathrm{NaCitrate}+$ $0.1 \%$ SDS. As probes for IL- $1 \beta$ and IL- 1 ra, the PCR amplified fragments were used, which had been subcloned into bluescript pSK ${ }^{+}$plasmid and confirmed by DNA sequencing. For autoradiography the blots were finally washed, dried and exposed to Hyperfilm-MP (Amersham International, Amersham, UK) overnight at $-70^{\circ} \mathrm{C}$ with an intensifying screen. The intensities of the spots obtained after autoradiography were quantitated by densitometry in a Beckman DU-62 spectrophotometer (Palo Alto, Calif., USA).

Bioactivity of IL-1 $\beta$. Groups of 500 freshly isolated islets were homogenized in $520 \mu \mathrm{l}$ redistilled water. Fractions $(2 \times 5 \mu \mathrm{l})$ of the aqueous homogenate were used for measurement of DNA content by fluorophotometry [29]. The remaining part of the homogenate was frozen and later analysed for $\mathrm{IL}-1 \beta$ bioactivity using the EL-4 murine T-cell line [30].

Immunohistochemistry. To study the distribution of macrophages in the pancreas of NOD mice, pancreata of female mice aged 5 and 16 weeks were removed, quickly frozen in liquid nitrogen and serially cryosectioned in $8-\mu \mathrm{m}$ thick sections. The sections were subsequently fixed for 3 min in $4 \%$ paraformaldehyde. Every second section was then stained either with antibodies against insulin or macrophage proteins. Insulin was demonstrated by the peroxidase-antiperoxidase (PAP)-technique [31]. The sections were incubated in $3 \% \mathrm{H}_{2} \mathrm{O}_{2}$ to block 


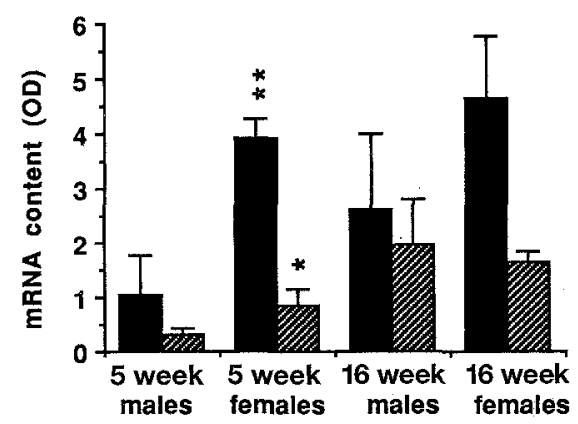

Fig. 1. IL-1 $\beta$ (口) and IL-1 ra (W) mRNA levels in freshly isolated NOD mouse islets, measured by a semi-quantitative PCR assay. The optical densities (OD) were normalized after parallel assay of GAPDH mRNA levels. Values are means \pm SEM for three experiments. $* p<0.05$ or $* * p<0.01$ vs corresponding values in islets isolated from 5-week-old male NOD mice

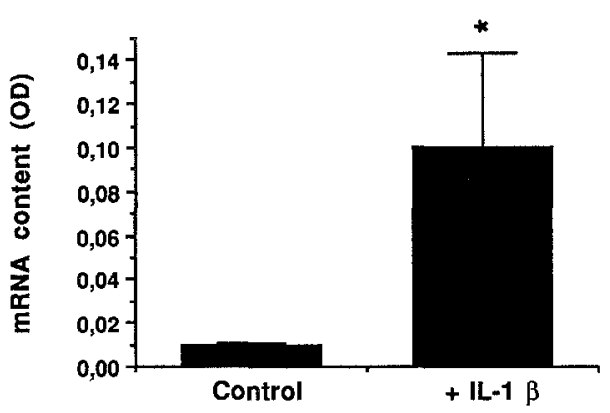

Fig. 2. Effect of IL $-1 \beta$ treatment on levels of IL- $1 \beta$ mRNA in islets isolated from NMRI mice. The islets were exposed for $48 \mathrm{~h}$ to $25 \mathrm{U} / \mathrm{ml}$ of IL-1 $\beta$. Values are means \pm SEM for three experiments. $* p<0.05$ vs control group

endogenous peroxidase activity and with normal swine serum (Dakopatts, Glostrup, Denmark) to block unspecific binding of the secondary antibody. Guinea-pig anti-bovine insulin serum $(1: 160)$ (Miles-Yeda, Rehovot, Israel) was used as primary antibody and swine anti-rabbit IgG (Dakopatts) as secondary antibody. The sections stained for macrophages were first incubated with normal goat serum (Dakopatts), and the sections were then incubated with the reagents of an avidin/ biotin blocking kit according to the manufacturer's instructions (Vector Laboratories, Burlingame, Calif., USA). The primary mouse macrophage antibody MAS034 [32, 33], kindly given by Dr. R. Holmdahl, Uppsala, Sweden, was subsequently added, and biotinylated goat anti-rabbit-IgG was applied as secondary antibody. Normal NMRI mouse serum was also added at this stage in order to avoid unspecific binding of the secondary antibody to the tissue. This was followed by detection using the avidin/biotin system (Vectastain ABC elite kit; Vector). Finally, the sections were stained by incubation in aminoethylcarbazole $/ \mathrm{H}_{2} \mathrm{O}_{2}$ and counterstained with haematoxylin.

Nitrite determination. Groups of 100 freshly-isolated islets, 6day cultured islets and cultured islets exposed to IL- $1 \beta$ were studied. Media samples $(80 \mu \mathrm{l})$ were deproteinized by addition of $20 \mu \mathrm{l} 35 \%$ sulfosalisylic acid (Sigma Chemicals, St.Louis, Mo., USA). Samples were incubated for $30 \mathrm{~min}$ at $0^{\circ} \mathrm{C}$ and subsequently centrifuged for $20 \mathrm{~min}$ at $12,000 \mathrm{~g}$. To the supernatants was added $10 \mu \mathrm{l}$ of $0.5 \%$ naphtylethylendiamine dihydrochloride (Sigma), $5 \%$ sulfanilamide (Sigma) and $25 \%$ concentrated $\mathrm{H}_{3} \mathrm{PO}_{4}$ [34]. The reaction was carried out at $60^{\circ} \mathrm{C}$ for $15 \mathrm{~min}$ and the absorbance at $546 \mathrm{~nm}$ was measured in a spectrophotometer against a standard curve. The nitrite production was investigated both acutely after islet isolation, after culture for 6 days and after another day in culture following medium exchange and addition of IL-1 $\beta(25 \mathrm{U} / \mathrm{ml})$.

\section{Statistical analysis}

For the PCR experiments, islets were isolated and pooled from the pancreatic glands of 7-8 female and male mice of the same age at each occasion. Furthermore, each individual determination represents a separate RNA isolation with all subsequent steps performed individually. Means \pm SEM were calculated, and female and male islets of the same age isolated in parallel were compared using Student's paired or unpaired $t$-test. In the experiments where IL- $1 \beta$ bioactivity was assessed, the data were compared using Wilcoxon's signed rank test.

\section{Results}

The determination of IL- $1 \beta$ mRNA by PCR amplification of cDNA from 16-week-old female NOD mice followed by Southern blot analysis indicated a linear reaction in that 10 and $5 \mathrm{ng}$ gave values of $61 \% \pm 27 \%(n=3)$ and $35 \% \pm 15 \%(n=3)$, respectively; the value for $15 \mathrm{ng}$ mRNA transcribed into cDNA ( $3 \mu$ of cDNA) was set to $100 \%$. The reactions for the other cDNA amplifications were also linear.

At 5 weeks of age, the IL- $1 \beta$ mRNA levels, normalized to parallel determination of GAPDH mRNA expression to compensate for differences in cell number, mRNA isolation and cDNA synthesis, were higher in islets isolated from NOD females compared to males (Fig.1). However, the IL-1 $\beta$ mRNA levels at 16 weeks of age in islets isolated from males were similar to those of the female NOD islets. In vitro culture of islets isolated from 16-weekold females, a procedure which markedly depletes the islet mononuclear cell infiltration [16], reduced the level of IL- $1 \beta$ mRNA expression by about $50 \%$ compared to freshly isolated islets (freshly isolated islets: $3.94 \pm 0.44$ optical density $(n=3)$ vs cultured islets $1.83 \pm 0.23$ optical density $(n=3) ; p<0.05)$.

IL-1 ra mRNA was also present in the NOD mouse islets (Fig. 1). At 5 weeks of age the level of this transcript was higher in the females. However, after 16 weeks the IL-1 ra mRNA contents reached similar levels in islets of both sexes.

Islets isolated from non-diabetes prone NMRI mice were also examined for the presence of IL- $1 \beta$ gene expression which was found to be extremely low (Fig. 2). However, if such islets were exposed to human IL-1 $\beta(25 \mathrm{U} / \mathrm{ml})$ for $48 \mathrm{~h}$, expression of the messenger for IL- $1 \beta$ increased about ten-fold.

The expression of iNOS mRNA in freshly-isolated NOD and NMRI mouse islets was very low (Table 1 ). Nevertheless, there were slightly higher levels of 
Table 1. Levels of iNOS mRNA expression in freshly-isolated mouse islets and in cultured RINm5F cells

\begin{tabular}{ll}
\hline Islet donor and treatment & iNOS mRNA (OD) \\
\hline $\begin{array}{l}\text { NOD females 5 weeks; } \\
\text { freshly isolated islets }\end{array}$ & $0.013 \pm 0.013$ \\
$\begin{array}{l}\text { NOD females } 16 \text { weeks; } \\
\text { freshly isolated islets }\end{array}$ & $0.157 \pm 0.046^{\mathrm{a}}$ \\
$\begin{array}{l}\text { NOD males 5 weeks; } \\
\text { freshly isolated islets }\end{array}$ & $0.023 \pm 0.023$ \\
NOD males 16 weeks; & \\
freshly isolated islets & $0.167 \pm 0.038^{\mathrm{a}}$ \\
NMRI males; cultured islets & $0.007 \pm 0.003$ \\
NMRI males $+25 \mathrm{U} / \mathrm{ml}$ IL-1 $\beta ;$ & $1.160 \pm 0.003^{\mathrm{a}}$ \\
cultured islets & \\
RINm5F cells & not detectable \\
RINm5F cells $+25 \mathrm{U} / \mathrm{ml} \mathrm{IL-1} \beta$ & $2.16 \pm 0.46$ \\
\hline
\end{tabular}

The optical density (OD) of the autoradiographs was normalized per GAPDH levels. Values are means \pm SEM for three experiments. ${ }^{a} p<0.05$ vs either corresponding islets of 5-weekold NOD mice or vs NMRI male islets not exposed to cytokine, using unpaired $t$-test

Table 2. DNA content and IL- $1 \beta$ activity in freshly-isolated islets from NOD and NMRI mice

\begin{tabular}{|c|c|c|c|}
\hline Group of islets & $n$ & $\begin{array}{l}\text { DNA content } \\
\text { ( } \mu \text { g DNA } \\
500 \text { islets })\end{array}$ & $\begin{array}{l}\text { IL- } 1 \beta \text { activity } \\
\text { (mU/ug } \\
\text { DNA) }\end{array}$ \\
\hline NOD; 5 weeks males & 6 & $18.9 \pm 2.1$ & $13 \pm 8^{\mathrm{b}}$ \\
\hline NOD; 5 weeks females & 6 & $21.0 \pm 1.1$ & $233 \pm 12$ \\
\hline NOD; 16 weeks males & 6 & $23.1 \pm 1.0^{\mathrm{a}}$ & $181 \pm 71$ \\
\hline NOD; 16 weeks females & 8 & $37.8 \pm 5.2$ & $200 \pm 52$ \\
\hline NMRI; 12 weeks males & 8 & $18.9 \pm 1.1$ & $8 \pm 5$ \\
\hline
\end{tabular}

Values are means \pm SEM for $n$ experiments. ${ }^{a} p<0.05$ vs 16 week-old females and ${ }^{\mathrm{b}} p<0.001$ vs 5 -week-old females, using Wilcoxon's signed rank test

iNOS mRNA in islets isolated from 16 week-old animals, compared to islets of the same sex isolated at 5 weeks of age. On the other hand, exposure in vitro to IL- $1 \beta$ strongly induced the transcript in NMRI mouse islets. The nitrite accumulation following incubation of freshly isolated or cultured islets from NMRI and NOD mice (5- and 16-week-old females and males) was negligible (Fig. 3). In line with the iNOS induction, addition of IL- $1 \beta$ to the cultured islets markedly increased medium nitrite accumulation in all groups of islets.

IL- $1 \beta$ mRNA could not be detected in RINm5F cells in three experiments, irrespective of IL- $1 \beta$ treatment or not (data not shown), whereas a strong iNOS mRNA signal was observed after incubation of these cells with IL-1 $\beta$ (Table 1 ).

The biological activity of IL- $1 \beta$, expressed per DNA, in homogenates of islets isolated from female mice at 5 weeks was much higher than in islets obtained from corresponding male mice (Table 2). However, the IL-1 $\beta$ activity was similar at 16 weeks

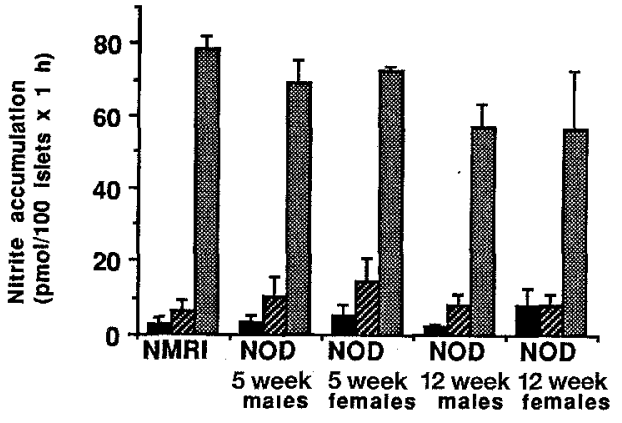

Fig. 3. Nitrite accumulation of freshly-isolated islets ( $\square$ ), cultured islets (W) and cultured islets exposed to IL-1 $\beta$ ( $25 \mathrm{U} /$ $\mathrm{ml}$ ) for $24 \mathrm{~h}$ ( The islets were isolated from male or female NOD mice at 5 or 16 weeks of age, or from 12-week-old male NMRI mice. Values are means \pm SEM for five experiments

of age in the islets isolated from females and males. The islet DNA content was higher in the islets of the females compared to the males at 16 weeks of age, suggesting a larger cellular infiltrate. The IL-1 $\beta$ activity in freshly-isolated NMRI islets was negligible.

Light microscopical examinations of pancreatic sections of 5- and 15-week-old NOD females revealed various degrees of insulitis (Fig.4). In general, more islets exhibited cell infiltration into the islets in the older animals. Macrophages were scattered in the exocrine as well as in the islet parenchyma; however, there was an accumulation of these cells in the peri-insular space (Fig.4). Since no morphometric analysis was performed we cannot determine if a difference in the content and distribution of macrophages in the pancreatic sections of 5-and 16-week-old mice existed. In the older animals the islet architecture had also frequently become disarranged.

\section{Discussion}

A crucial point in understanding the putative role of $\mathrm{IL}-1 \beta$ in the pathogenesis of IDDM is to assess the expression of this gene in islets of animals developing diabetes. The present investigation demonstrates that islets isolated from NOD mice contain measurable levels of IL- $1 \beta$. It is likely that the IL $-1 \beta$ is mainly produced by intra-islet and peri-insular macrophages, since these cells have previously been observed among the infiltrating cells in NOD mice [35-38] and in BB rats [12,39-41], and were readily detected in female NOD mouse islets both at 5 and 16 weeks of age. It has recently been reported that beta-cell destruction observed in NOD mice is initiated by activation of T-cell clones reactive against the beta-cell autoantigen glutamic acid decarboxylase [42, 43]. This initial loss of self-tolerance was followed by the activation of T-cell clones reactive to several other beta-cell autoantigens and a gradual build-up of the insulitis. Although the latter model for IDDM in the 

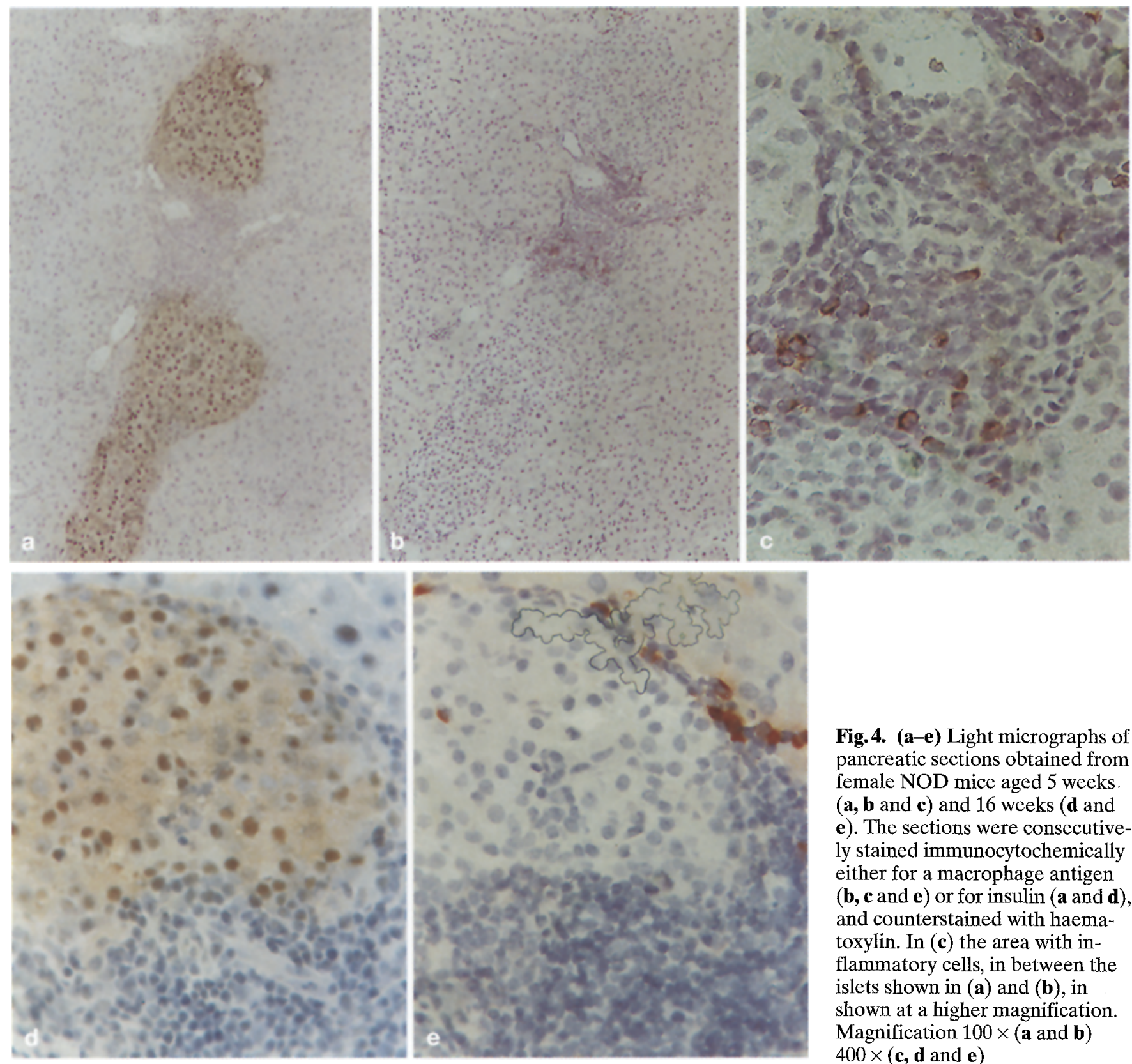

Fig. 4. (a-e) Light micrographs of pancreatic sections obtained from female NOD mice aged 5 weeks (a, b and $\mathbf{c}$ ) and 16 weeks (d and e). The sections were consecutively stained immunocytochemically either for a macrophage antigen (b, c and e) or for insulin (a and d), and counterstained with haematoxylin. In (c) the area with inflammatory cells, in between the islets shown in (a) and (b), in shown at a higher magnification. Magnification $100 \times(\mathbf{a}$ and $\mathbf{b})$ $400 \times(\mathbf{c}, \mathbf{d}$ and $\mathbf{e})$

NOD mouse emphasizes the role of T-cells, it does not exclude an important role of macrophages as antigen presenting cells and/or cytokine-producing cells capable of modulating the process of autoimmune destruction of beta-cells.

In the present investigation, it was observed that islets from male NOD mice clearly exhibited lower levels of IL- $1 \beta$ activity at 5 weeks of age than islets from the corresponding female mice. Since the diabetes incidence is markedly higher in females than in males, the difference in IL- $1 \beta$ levels may reflect early events in a process eventually leading to beta-cell destruction and diabetes. This study does not, however, address the role of IL- $1 \beta$ released locally in the vicinity of the islets as a $T$-cell coactivator, and thus it is unclear to what extent high levels of IL- $1 \beta$ contribute to diabetes susceptibility.

The present study points also to the presence of IL-1 ra in NOD mouse islets, as assessed by IL-1 ra mRNA determinations. IL-1 ra is produced by activated macrophages and acts by binding competitively the type $1 \mathrm{IL}-1$ receptor without activating it [17]. Clearly, IL-1 ra activities must be taken into account when considering the putative role of IL-1 $\beta$ in IDDM [44]. As currently observed with IL- $1 \beta$, IL1 ra mRNA levels were lower in islets of male NOD mice at 5 weeks of age, but similar to islets of female mice at 16 weeks of age. Thus, no simple relationship between IL-1 ra and diabetes progression has been revealed. 
An interesting finding in the present study was that IL- $1 \beta$ in vitro induced a tenfold IL- $1 \beta$ mRNA expression in the islets of NMRI mice. This suggests that IL- $1 \beta$ induced expression of the IL- $1 \beta$ gene, presumably occurring in resident macrophages [45], may lead to accelerated beta-cell damage. It is thus worthy of note that purified rat beta-cells are less sensitive to cytotoxicity induced by IL- $1 \beta$ in vitro, than beta-cells situated within intact isolated islets [46] containing residual macrophages and endothelial cells. The current finding that the RINm5F cells did not express IL- $1 \beta$ mRNA following exposure to IL- $1 \beta$ may indicate that beta-cells are not the source of the IL-1 $\beta$ mRNA transcript. It must, however, be kept in mind that the RINm5F cells are not necessarily representative of normal islet cells.

It is well documented that IL-1 $\beta$ added in vitro to rodent islets, isolated beta-cells and insulin-producing cell lines induces NO formation [7-9, 47-50] and that the beta-cell inhibitory action of IL- $1 \beta$ is related to NO formation [7-9, 49]. Transcription and translation of the iNOS messenger has been demonstrated in the islets of pre-diabetic BB rats, mainly in macrophages, but possibly also in other cells in the vicinity of the macrophages [12]. Thus, high concentrations of IL- $1 \beta$ released locally by activated macrophages may stimulate adjacent beta-cells to produce NO leading to beta-cell suppression. We therefore examined whether the IL-1 $\beta$ mRNA levels observed in the NOD islets were associated with elevated IL-1 $\beta$ activity causing increased NO production. The data in Table 1 suggest that there is an induction of the iNOS gene both in the freshly-isolated female and male NOD islets between 5 and 16 weeks of age. However, the findings that the nitrite production was similar in freshly isolated NOD mouse and in control NMRI mouse islets suggest that the local concentrations of IL- $1 \beta$ in the NOD islets were too low to induce iNOS enough to cause a detectable NO synthesis. The possibility that the NOD mouse islets were unable to respond to IL- $1 \beta$, due to either a genetic or functional inability, is contradicted by the observation that high levels of NO in response to the cytokine were generated during culture. Moreover, recent reports showed that aminoguanidine, a preferential inhibitor of NOS [51, 52], failed to counteract IDDM in irradiated male NOD mice rendered diabetic by splenocyte transfer from diabetic female NOD mice [53] and mice treated with multiple low doses of streptozotocin [54]. However, we cannot exclude the possibility that IL- $1 \beta$ release and iNOS induction was localized to a minor fraction $(<5 \%)$ of the islets at a given time point, which would not be possible to detect in a homogenate of a mixture of NOD mouse islets. Furthermore, it is conceivable that the islets with the most severe insulitis and perhaps the highest iNOS activity, are preferentially lost during the islet isolation procedure.
In conclusion, our results do not reveal a simple relationship between direct beta-cell destruction, the difference in incidence of diabetes in female and male NOD mice and levels of IL- $1 \beta$, IL- 1 ra and NO in these islets. The role of early elevations in islet IL$1 \beta$ levels for the development of IDDM, as observed in female mice, remains to be established.

Acknowledgements. We are grateful for the skilled technical assistance by Ms. E. Forsbeck, Ms. M. Thomsen and Ms. L. Bredahl. This study was supported by grants from the Swedish Medical Research Council (12X-109; 12X-8273; 12X9884; 12X-9886; 12X-10822; 12P-10151; 12P-10739), the Swedish Diabetes Association, the Nordic Insulin Fund, Aage Louis-Hansens Mindefond, the Procordia Research Fund, the Ernfors Family Fund, the Juvenile Diabetes Foundation International, Barndiabetesfonden, the Danish Medical Research Council and the Danish Biotechnology Programme.

\section{References}

1. Nerup J, Mandrup-Poulsen T, J Mølvig J (1978) The HLAIDDM association: implications for etiology and pathogenesis of IDDM. Diab/Metab Rev 3: 779-802

2. Bendtzen K (1989) Immune hormones (cytokines); pathogenic role in autoimmune rheumatic and endocrine diseases. Autoimmunity 2: 177-189

3. McDaniel ML, Hughes JH, Wolf BA, Easom RA, Turk J (1989) Descriptive and mechanistic considerations of interleukin 1 and insulin secretion. Diabetes 37: 1311-1315

4. Mandrup-Poulsen T, Helqvist S, Mølvig J, Wogensen LD, Nerup J (1989) Cytokines as immune effector molecules in autoimmune endocrine diseases with special references to insulin dependent diabetes mellitus. Autoimmunity 4: 191218

5. Sandler S, Eizirik DL, Svensson C, Strandell E, Welsh M, Welsh N (1991) Biochemical and molecular actions of interleukin- 1 on pancreatic $\beta$-cells. Autoimmunity 10: 241-253

6. Rabinovitch A (1993) Role of cytokines in IDDM pathogenesis and islet $\beta$-cell destruction. Diabetes Rev 1: 215 240

7. Southern C, Schulster D, Green IC (1990) Inhibition of insulin secretion by interleukin- $1 \beta$ and tumour necrosis factor- $\alpha$ via an $\mathrm{L}$-arginine-dependent nitric oxide generating mechanism. FEBS Lett 276: 42-44

8. Welsh N, Eizirik DL, Bendtzen K, Sandler S (1991) Interleukin- $1 \beta$-induced nitric oxide production in isolated rat pancreatic islets requires gene transcription and may lead to inhibition of the Krebs cycle enzyme aconitase. Endocrinology 129: 3167-3173

9. Corbett JA, Lancaster Jr. JR, Sweetland MA, McDaniel ML (1991) Interleukin- $\beta$-induced formation of EPR-detectable iron-nitrosyl complexes in islets of Langerhans. Role of nitric oxide in interleukin- $\beta$-induced inhibition of insulin secretion. J Biol Chem 266: 21351-21354

10. Jiang Z, Woda BA (1991) Cytokine gene expression in the islets of the diabetic Biobreeding/Worcester rat. J Immunol 146: 2990-2994

11. Deyerle KL, Sims JE, Dower SK, Bothwell MA (1992) Pattern of IL-1 receptor gene expression suggests role in noninflammatory processes. J Immunol 149: 1657-1665

12. Kleemann R, Rothe H, Kolb-Bachofen V et al. (1993) Transcription and translation of inducible nitric oxide synthase in the pancreas of prediabetic BB rats. FEBS Lett 328: $9-12$ 
13. Leiter EH, Prochazka M, Coleman DL (1987) Animal model of human disease. The non-obese diabetic (NOD) mouse. Am J Pathol 128: 380-383

14. Lampeter EF, Signore A, Gale EAM, Pozzill P (1987) Lessons from the NOD mouse for the pathogenesis and immunotherapy of human type 1 (insulin-dependent) diabetes mellitus. Diabetologia 32: 703-708

15. Pozzilli P, Signore A, Williams AJK, Beales PE (1993) NOD mouse colonies around the world - recent facts and figures. Immunol Today 14: 193-196

16. Strandell E, Eizirik DL, Sandler S (1990) Reversal of $\beta$-cell suppression in vitro in the pancreatic islets isolated from nonobese diabetic mice during the phase preceding insulindependent diabetes mellitus. J Clin Invest 85: 1944-1950

17. Arend WP (1991) Interleukin 1 receptor antagonist. A new member of the interleukin-1 family. J Clin Invest 88: 14451451

18. Sandler S, Andersson A, Hellerström C (1987) Inhibitory effects of interleukin 1 on insulin secretion, insulin biosynthesis and oxidative metabolism of isolated rat pancreatic islets. Endocrinology 121: 1424-1431

19. Gazdar AF, Chick WL, Oie HK et al. (1980) Continuous, clonal insulin- and somatostatin-secreting cell lines established from a transplantable rat islet cell tumor. Proc Natl Acad Sci USA 77: 3519-3523

20. Gray PW, Glaister D, Chen E, Goeddel DV, Pennica D (1986) Two interleukin 1 genes in the mouse: cloning and expression of the cDNA for murine interleukin $1 \beta$. J Immunol 137: 3644-3648

21. Eisenberg SP, Evans RJ, Arend WP et al. (1990) Primary structure and functional expression from complementary DNA of human interleukin-1 receptor antagonist. Nature 343: 341-346

22. Lyons CR, Orloff GJ, Cunningham JM (1992) Molecular cloning and functional expression of an inducible nitric oxide synthase from a murine macrophage cell line. J Biol Chem 267: 6370-6374

23. Xie Q-w, Cho HJ, Calaycay J et al. (1992) Cloning and characterization of inducible nitric oxide synthase from mouse macrophages. Science 256: 225-228

24. Lowenstein CJ, Glatt CS, Bredt DS, Snyder SH (1992) Cloned and expressed macrophage nitric oxide synthase contrasts with the brain enzyme. Proc Natl Acad Sci USA 89: 6711-6715

25. Allen RW, Trach KA, Hoch JA (1987) Identification of the $37-\mathrm{kDa}$ protein displaying a variable interaction with the erythroid cell membrane as glyceraldehyde-3-phosphate dehydrogenase. J Biol Chem 262: 649-653

26. Mares J, Welsh M (1993) Expression of certain antiproliferative and growth-related genes in isolated mouse pancreatic islets: analysis by polymerase chain reaction. Diabete Metab 19: 315-320

27. Rosnet O, Marchetto S, deLapeyriere O, Birnbaum D (1991) Murine Flt3, a gene encoding a novel tyrosine kinase receptor of the PDGFR/CSF 1R family. Oncogene 6: 1641-1650

28. Southern EM (1975) Detection of specific sequences among DNA fragments separated by gel electrophoresis. J Mol Biol 98: 503-517

29. Hinegardner RT (1971) An improved fluorometric assay for DNA. Anal Biochem 39: 197-201

30. Svenson M, Bendtzen K (1988) Interleukin 1 inhibitor in normal human urine. Different effects on mouse thymocytes and on a murine T-cell line. Scand J Immunol 27: 593-599

31. Sternberger LA, Hardy PH, Cuculis JJ, Meyer HG (1970) The unlabeled antibody enzyme method of immunohisto- chemistry. Preparation and properties of soluble antigenantibody complex (horseradish peroxidase-anti-horseradish peroxidase) and its use in identification of spirochetes. I Histochem Cytochem 18: 315-333

32. Kraal G, Janse M (1986) Marginal metallophilic cells of the mouse identified by a monoclonal antibody. Immunology 58: 665-669

33. Holmdahl R, Tarkowski A, Jonsson R (1991) Involvement of macrophages and dendritic cells in synovial inflammation of collagen induced arthritis in DBA/1 mice and spontaneous arthritis in MRL/Lpr mice. Autoimmunity 8: 271280

34. Green LS, Wagner DA, Glogowski J, Skipper PL, Wishnok JS, Tannenbaum SR (1982) Analysis of nitrate, nitrite and $\left[{ }^{15} \mathrm{~N}\right]$ nitrate in biological fluids. Anal Biochem 126: $131-138$

35. Lee K-U, Yoon J-W (1988) Evidence for initial involvement of macrophage in development of insulitis in NOD mice. Diabetes 37: 989-991

36. Ihm S-H, Yoon J-W (1990) Studies on autoimmunity for initiation of $\beta$-cell destruction. VI. Macrophages essential for development of $\beta$-cell-specific cytotoxic effectors and insulitis in NOD mice. Diabetes 39: 1273-1278

37. Reddy S, Liu W, Elliot RB (1993) Distribution of pancreatic macrophages preceding and during early insulitis in young NOD mice. Pancreas 8: 602-608

38. Jansen A, Homo-Delarche F, Hooijkaas H, Leenen PJ, Dardenne M, Drexhage HA (1994) Immunohistochemical characterization of monocytes-macrophages and dendritic cells involved in the initiation of the insulitis and $\beta$-cell destruction in NOD mice. Diabetes 43: 667-675

39. In't Veld PA, Pipeleers DG (1988) In situ analysis of pancreatic islets in rats developing diabetes. Appearance of nonendocrine cells with surface $\mathrm{MHC}$ class II antigens and cytoplasmic insulin immunoreactivity. J Clin Inves 82: 1123-1218

40. Walker R, Bone AJ, Cooke A, Baird JD (1988) Distinct macrophage subpopulations in pancreas of prediabetic $\mathrm{BB} / \mathrm{E}$ rats. Possible role of macrophages in pathogenesis of IDDM. Diabetes 37: 1301-1304

41. Hanenberg H, Kolb-Bachofen V, Kantwerk-Funke G, Kolb $H$ (1989) Macrophage infiltration precedes and is a prerequisite for lymphocytic insulitis in pancreatic islets of prediabetic BB rats. Diabetologia 32: 126-134

42. Kaufman DL, Clare-Salzler M, Tian J et al. (1993) Spontaneous loss of T-cell tolerance to glutamic acid decarboxylase in murine insulin-dependent diabetes. Nature 366: 6972

43. Tisch R, Yang X-D, Singer SM, Liblau RS, Fugger L, McDevitt HO (1993) Immune response to glutamic acid decarboxylase correlates with insulitis in non-obese diabetic mice. Nature 366: 72-75

44. Mandrup-Poulsen T, Zumsteg U, Reimers J et al. (1993) Involvement of interleukin 1 and interleukin 1 antagonist in pancreatic $\beta$-cell destruction in insulin-dependent diabetes mellitus. Cytokine 5: 185-191

45. Dinarello CA (1991) Interleukin-1 and interleukin-1 antagonism. Blood 77: 1627-1652

46. Ling Z, In't Veld PA, Pipeleers DG (1993) Interaction of interleukin- 1 with islet $\beta$-cells. Distinction between indirect, aspecific cytotoxicity and direct, specific functional suppression. Diabetes 42: 56-65

47. Eizirik DL, Cagliero E, Björklund A, Welsh N (1992) Interleukin- $1 \beta$ induces the expression of an isoform of nitric oxide synthase in insulin-producing cells, which is similar to that observed in activated macrophages. FEBS Lett 308: 249-252 
48. Eizirik DL, Björklund A, Welsh N (1993) Interleukin-1-induced expression of nitric oxide synthase in insulin-producing cells is preceded by c-fos induction and depends on gene transcription and protein synthesis. FEBS Lett 317: 62-66

49. Corbett JA, Wang JL, Sweetland MA, Lancaster Jr. JR, McDaniel ML (1992) Interleukin $1 \beta$ induces the formation of nitric oxide by $\beta$-cells purified from rodent islets of Langerhans. Evidence for the $\beta$-cell as a source and site of action of nitric oxide. J Clin Invest 90: 2384-2391

50. Cetkovic-Cvrlje M, Sandler S, Eizirik DL (1993) Nicotinamide and dexamethasone inhibit interleukin-1-induced nitric oxide production by RINm 5 F cells without decreasing messenger ribonucleic acid expression for nitric oxide synthase. Endocrinology 133: 1739-1743
51. Corbett JA, Tilton RG, Chang Cet al. (1992) Aminoguanidine, a novel inhibitor of nitric oxide formation, prevents diabetic vascular dysfunction. Diabetes 41: 552-556

52. Misko TP, Moore WM, Kasten TP et al. (1993) Selective inhibition of the inducible nitric oxide synthase by aminoguanidine. Europ J Pharmacol 233: 119-126

53. Corbett JA, Mikhael A, Shimizu J et al. (1993) Nitric oxide production in islets from nonobese diabetic mice: aminoguanidine-sensitive and -resistant stages in the immunological process. Proc Natl Acad Sci USA 90: 8992-8995

54. Holstad M, Sandler S (1993) Aminoguanidine, an inhibitor of nitric oxide formation, fails to protect against insulitis and hyperglycemia induced by multiple low dose streptozotocin injections in mice. Autoimmunity 15: 311-314 